
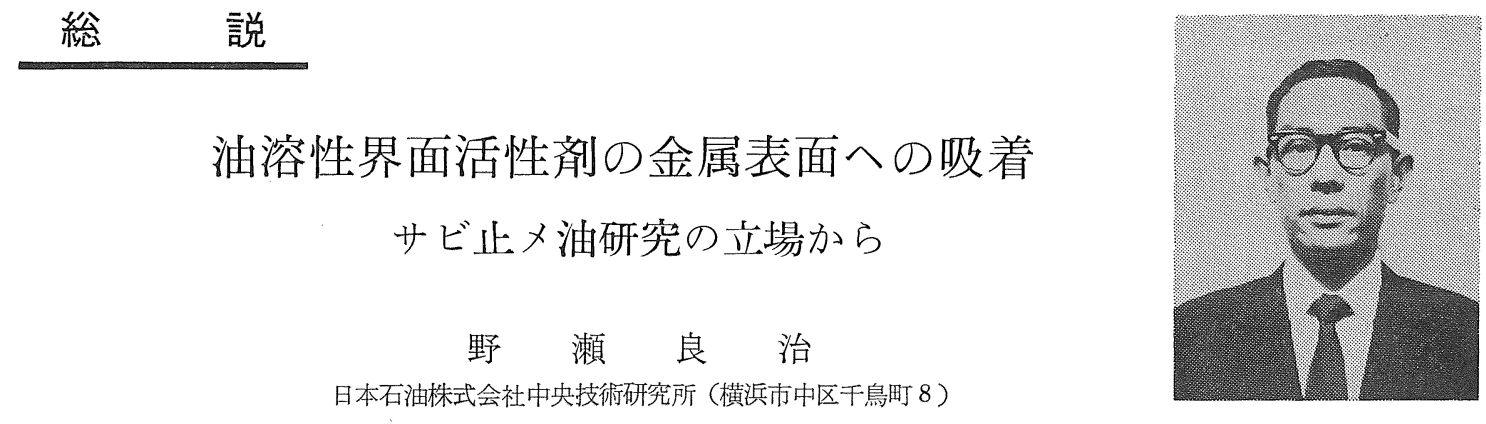

\title{
Adsorption of Oil Soluble Surfactants on Metals
}

A Review from the Viewpoint of Rust Preventive Oils

Yoshiharu Nose

The Central Technical Research Laboratory, Nippon Oil Co., Ltd. (Naka-ku, Yokohama)

\section{1 はじめに}

油溶性界面活性剂が石油製品の添加剂として広く応用 されていることは最近の本誌上で紹介されているとおり であるが1)，これらが境界潤滑剂あるいはサビ止メ剂と して用いられる場合に金属面に打ける吸着がその作用機 構上もっとも重要な現象であることは過去数十年間にわ たる数多くの研究によって明らかにされてきた。サビ止 メ剤ではサビ発生の原因が多種多様であるために，その サビ止メ作用も種々の因子に分けて考えるべきであり， 単純に吸着現象の面だけからとらえることはできない。 しかし, 最近までに集積された油溶性界面活性剤の金属 表面への吸着に関する研究成果をサビ止メ剂を研究する 立場加あらためてまとめて見ることはこの分野におけ る今後の発展にとって意義あるものと思われる。本報で はサビ止メ剂の吸着に関連する諸問題とともに, サビ止 メ油の実用性能を論じる上で興味のある二, 三の問題に ついても触れてみたい。

\section{2 吸着現象と研究方法}

サビ止メ油および潤滑油のサビ止メ剂として用いられ る油溶性界面活性剤は主としてカルボン酸, カルボン酸 塩, スルホネート, アミン類, エステル類およびリン酸 誘導体である。これらは普通, 石油留分のような炭化水 素の溶液として用いられる。したがって, 本報ではこれ らの無極性溶液からの金属面への吸着を論じることにな る。

後述するように，サビ止メ剂の吸着に影響する因子は 多くしかも相互に関係し合うために複雑であるが, 各論 にはいる前にまず研究方法とそれによって得られた吸着 現象の概略を紹介する。
吸着現象 の研究は（1）熱力学, (2) 速度論, (3) 分 子あるいは原子間相互作用の三つを基礎としている。こ れらは具体的にはそれぞれ吸着平衡，吸着速度および吸 着様式の研究になる。このらち前 2 者を明らかにするた めに必要な測定は吸着量である。溶液加金属面への溶 質の吸着量をそのままの状態で直接測定するには，放射 性同位元素 (以下 RI と略す) で標識した界面活性荗の 溶液中に，被吸着金属で表面をコーチングした端空型の 放射線計数管を浸セキし，吸着によって増加する放射線 強度を測定し，これから吸着量を算出する方法が用いら れる ${ }^{2) \sim 4}$ 。Smith ら ${ }^{4)}$ はこの方法によって ${ }^{35} \mathrm{~S}$ 標識ジノ ニルナフタリンスルホン酸 (以下 DNNS と略す) の $\mathrm{Ca}$ 塩のホワイトオイル溶液から $\mathrm{Au}$ 面への吸着を測定 した。図-1 に示すように，時間とともに吸着量は増加 するがやがて平衡值に達する。この平衡吸着量から計算 される 1 分子あたりの占有面積は $125 \AA^{2}$ で,水面上に作 った $\mathrm{Ca}(\mathrm{DNNS})_{2}$ の最チュウ密配列と考えられる単分 子膜中の 1 分子当たりの占有面積にほぼ等しいことから， $\mathrm{Ca}(\mathrm{DNNS})_{2}$ は $\mathrm{Au}$ 上でも同様な単分子層を形成して

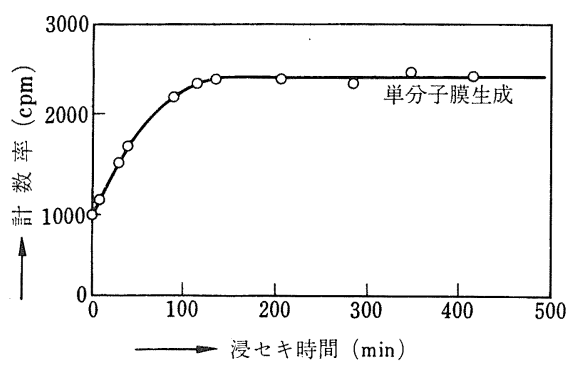

図-1 ジノニルナフタリンスルホン酸 カルシウムの金表面への吸着 (ホワイトオイル溶液, 室温 $)^{4)}$ 
いることがわかる。一方, Ries ら ${ }^{3)}{ }^{14} \mathrm{C}$ 標識ステア リン酸の $n$-ヘキサデカン溶液から $\mathrm{Au}, \mathrm{Fe}$, 抒よび $\mathrm{Cu}$ への吸着を空気中およびへリウム中でしかも乾燥時と水 蒸気飽和時を組み合わせて測定している。結果はふんい 気と金属によって異なり，たとえば $\mathrm{Fe}$-乾燥空気では 最チュウ密配列の単分子吸着が起こるが, $\mathrm{Au}$-乾燥空気 では 0.6 分子層しか吸着しない。これらの場合にはいず れも $5 \mathrm{hr}$ 以内に吸着平衡に達しているが， $\mathrm{Cu}$-加湿空気 では図-2 に示すように $70 \mathrm{hr}$ にわたって吸着量が増加 し8 分子層以上の多分子吸着をすることを示している。

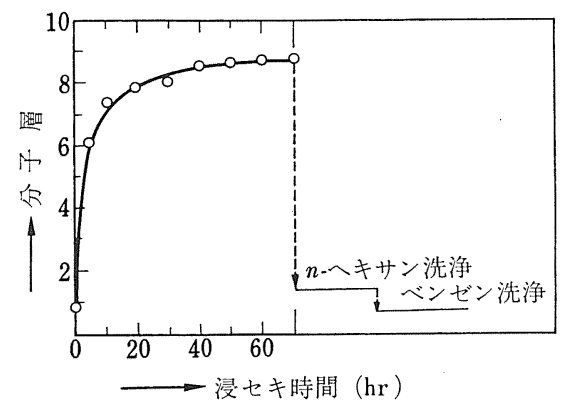

図-2 ステアリン酸の銅表面への吸着 $\left(\text { n-ヘキサデカン溶液, } 35^{\circ} \mathrm{C}\right)^{3)}$

吸着量の測定でもっとも一般的な方法は, 試料溶液に 試験片を一定時間浸セキするかあるいは試験片に溶液を 塗布して吸着させたのち, 表面に付着している余分の溶 液を口紙なででふき取って吸着量を測定する方法であ る。もし吸着膜が自己疎液性 ${ }^{5}$ のときは溶液が表面に残 らないから実験が簡単になる。Zisman ら ${ }^{6)}$ はこを retract 法と名付けている。この方法を用いるために, 溶媒として表面張力の大きい二トロメタンクなどが意識 的に用いられることがある。このようにして得られた吸 着膜の吸着量は前述の直接測定法と同時に RI 標識化合 物を用いれば放射能測定からただちに求められるが，間 接的にはエリプソメトリー ${ }^{8)}$ あるいは反射赤外線吸収 スペクトル によって求めた膜厚を分子層に換算する方 法, 表面電位加求める方法 ${ }^{10)}$ が行なわれている。この ような間接的な方法はいずれも RI を用いるかあるいは 水面上やその他の方法で作った単分子膜の測定值を用い て吸着量を較正する。このほか粉末試料の場合には吸着 の絶体量が多いので吸着前後の溶液濃度の差から吸着量 が計算できる ${ }^{11), 12) 。 ~}$

吸着量を厳密に測定するには吸着面の真の表面積を測 定しなければならない。粉末試料の表面積は通常の $\mathrm{BE}$ $\mathrm{T}$ 法で測定される。金属板の表面積は電子顕微鏡によ る観察 ${ }^{13}$ やステアリン酸のように最チュウ密配列の単分 子吸着をするとされている物質を吸着させ，1分子当た りの占有面積から計算する方法 ${ }^{4}$ で求められている。 しかし, 最近は小型の質量分析器を用いる感度の高い表
面積測定法が進歩している ${ }^{14)}$ ので今後はこのような方法 が用いられるであろら。

つぎに吸着膜の構造や吸着の相互作用を研究する方法 について述べよう。測定手段としては電子顕微鏡, 電子 回折, 表面電位, 赤外線吸収スペクトルおよび吸着膜上 の接触角の測定がある。吸着膜の研究には上述のように 溶液加らの吸着膜を用いるほかに, Langmuir-Blodgett 法で水面上に作った単分子膜を金属面に移しとる方法が よく用いられる。Gaines ${ }^{15)}$ は図-3 に示すよらに水面 上の任意の表面濃度のステアリン酸単分子膜を同一濃度 で固体表面に移し取ることができるとしている。しかし Ellison $^{16)}$ や Smith ${ }^{17)}$ はステアリン酸の 単分子膜の吸 着状態が表面圧がそれほど高くない領域では水面上と水 銀上でいちじるしく異なっていることを明らかにしてい るので，たとえ同一濃度であっても金属上では配列のち がう可能性があると思われる。このほか試料をつけた表 面を清浄な紙その他で強くこすることによってもチュウ 密配列の分子膜が得られる ${ }^{18)}$ 。

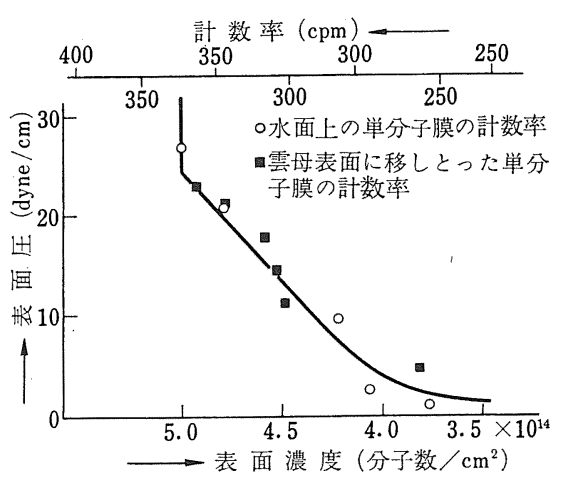

図-3 水面上のステアリン酸単分子膜の 雲母上への転写 ${ }^{15}$

Grindstaff ら ${ }^{13}$ は $\mathrm{Cu}$ の平滑な単結晶面に $n$-ノナデカ ン酸をシクロヘキサン溶液加ら吸着させたときの吸着膜 を電子顕微鏡により観察し, 表面被覆率(最チュウ密配列 単分子層の被覆率を 1 とする) が小さい吸着初期の吸着 膜は島状に存在することを明らかにした。島の高さは測 定䛊差を考慮すると酸の分子長に近い。Brockway ら ${ }^{19)}$ はガラス面上ではあるが長鎖脂肪酸で同様な結果を得て いる。島状に吸着する理由はつぎのように説明されてい る。脂肪酸のカルボン酸基の占有面積は $20.5 \AA^{2}$, 炭化 水素基の断面積は $18 \AA^{2}$ である ${ }^{20), 21)}$ から，分散力によ って炭化水素基が引き合うと 図-4に示すように垂直の

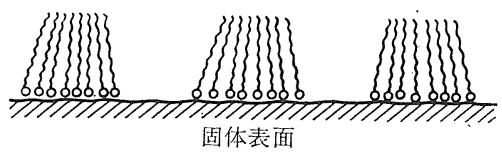

図-4 直鎖脂肪酸単分子膜の構造 
配列を取らなくなり, 横方向に吸着膜が生長しにくくな る。Brockway らはさらに一面に成長した単分子膜でも 穴があることを見いだしたが Grindstaff らは認めてい ない。Brockway らはオクタデシルアミン, ステアリン 酸 $\left(\mathrm{C}_{18}\right)$ おおよびセロチン酸 $\left(\mathrm{C}_{25}\right)$ の $\mathrm{Pt}^{22)}$ および $\mathrm{Cu}$, $\mathrm{Fe}, \mathrm{Al}^{23)}$ の単分子膜の電子回折を測定し，いずれの場 合にも吸着分子が垂直に配列していることを確かめた。

以上の結果加ら少なくとも直鎖上の界面活性剤は表面 に垂直な単分子膜を作ることがわかるが, さらに各分子 が極性基を金属側に向けていることは，Zisman ら により脂肪族アミンや脂肪酸の単分子膜が表面電位を示 すことによって明らかにされている。このほか Martin $ら^{25), 26)}$ 扝よび Fowkes ${ }^{10)} ら も$ 同様にして極性基が金属 表面に吸着することを報告している。これらの研究で測 定された表面電位から下式により計算される双極子能率 の垂直成分は分子自体のもつ双極子能率より小さい。

$$
\begin{aligned}
\Delta V=4 \pi n \mu p \\
\Delta V: \text { 表面電位, } \\
n: \text { 単位面積中の分子数, } \\
\mu p: \text { 双極子能率の垂直成分 }
\end{aligned}
$$

この原因については吸着分子の双極子のベクトル方向 が垂直に対して傾いていることが主要な要因であるが， そのほか分子の永久双極子によって金属表面に誘起され る逆方向の電気 2 重層や金属表面に吸着している水の影 響などが考えられており ${ }^{24), 25)}$ ，表面電位の峳密な解釈 は今後の問題である。一方, 吸着膜の外側の構造に関し ては，Zisman の長年にわたる 自己疎液性単分子膜の研 究で確立された臨界表面張力を測定する ${ }^{27)}$ か，さらに簡 単には単分子膜の溶解度が小さく表面張力の大きいヨウ 化メチレンのような 液体の接触角を測定する ${ }^{24), 28)} こ と$ により情報が得られる。この方法によって Timmons $ら^{24)}$ は Pt 表面では炭素数 14 以上, $\mathrm{NiO}$ 上では炭素 数 9 以上の直鎖脂肪酸の平衡吸着膜の表面はメチル基で 覆われており，脂肪酸が表面に垂直に配列していること を証明した。また Singleterry ら ${ }^{27)}$ は各種の DNNS 塩
で同様な測定を行なっているがこれについては後述す る。

これまでに紹介した研究結果から油溶性界面活性剤分 子は少なくとも永久双極子による静電引力によって金属 表面に吸着し，さらに炭化水素基間の分散力によって横 方向の配列をすることが明らかであるが，以下のように 吸着膜中の分子の吸着力に差があることや, 金属や水分 の影響によって吸着性が異なることから上記の相互作用 より強い相互作用があることがわかっている。Timmo$\mathrm{ns}$ ら $^{28)}$ はステアリン酸の $\mathrm{Fe}$ 上の単分子膜の加熱およ び溶媒による脱着を RI 法および接触角法で調べた結 果，図-5に示すように吸着分子の $40 \%$ は脱着されす に残ることからこれらが不可逆吸着すなわち化学吸着を していると推定した。Block ら ${ }^{29}$ は軟鋼上のステアリン 酸について 同様な結果を得ている。また Schonhorn ${ }^{30)}$ は $\mathrm{Al}$ 上のステアリン酸の単分子膜を加熱するとベンゼ ンで脱着できない部分が増加することを見いだした。こ のほか軟鋼上のスルホネートでも水分の存在によって不 可逆吸着が促進されることが Hong ら ${ }^{31}$ によって報告 されている。

このような 化学吸着の存在は吸着熱 ${ }^{32)}$ の測定によっ てもわかるが，より直接的で簡単な方法は赤外線吸収ス ペクトルである。測定法は (1) 透過法 ${ }^{33)}{ }^{34)}$ ，(2) 発光 法 $^{35)}{ }^{36)}$ ，(3) 反射法 ${ }^{37)}$, 39) がある。透過法は粉末の被吸 着物質を高圧でプレスして透明な板とし，これを溶液中 に浸セキして吸収スペクトルを測定する。この際標準試 料側に溶液を置いて補償すれば吸着膜のみのスペクトル が得られる。この方法の利点は溶液からの吸着をそのま まの状態で測定できることであるが，金属は透明になら ないので測定できない欠点がある。Hasegawa らはこれ によって $\mathrm{SiO}_{2}{ }^{40)}, \mathrm{Al}_{2} \mathrm{O}_{3}{ }^{40)}, \mathrm{MgO}^{40)}, \mathrm{ZnO}^{34)}$ へのステア リン酸, デカン酸の吸着を研究している。この結果によ ると $\mathrm{SiO}_{2}$ のように直鎖脂肪酸と反応しない場 合には $1,735 \mathrm{~cm}^{-1}$ 付近のカルボン酸のモノマーの $\mathrm{C}=\mathrm{O}$ によ る吸収しか現われないので, これらの酸は物理吸着であ

ることを示す。一方, $\mathrm{Al}_{2} \mathrm{O}_{3}$, $\mathrm{MgO}$ および $\mathrm{ZnO}$ の場合に はいすれれもそぞれのカル ボン酸金属塩による 1,600 $\mathrm{cm}^{-1}$ 近傍の吸収が観測され， 明らかに化学吸着をしてい る。とくに $\mathrm{MgO}$ および $\mathrm{ZnO}$ 上の吸着膜は結晶状のカルボ ン酸塩の特徴であるメチレン 基の Wagging 振動による $1,200 \sim 1,300 \mathrm{~cm}^{-1}$ の吸収を 示すからチュウ密配列の吸着 をしているものと考えられ 
る。また溶液の濃度を上げると脂肪酸のダイマーによる $1,700 \mathrm{~cm}^{-1}$ の吸收が現われ，二次的に酸の物理吸着が 起こることがわかる。このように，溶液と接している 吸着面には固体上に単分子吸着しているものとさらにそ の上層に多分子吸着しているものがあると思われる。つ ぎに発光法は金属上に吸着膜を作り，これを $100^{\circ} \mathrm{C}$ 以 上に加熱して自らを光源とする測定法である。Low ら はオレイン酸などの不飽和脂肪酸およびステアリン酸の $\mathrm{Fe}^{35)}$ および $\mathrm{Cu}^{36)}$ 上の吸着膜のスペクトルを測定し， はじめに下図（a）のようなエステル構造をもつ吸着種 ができるが，これがさらに（b）のような Binuclear 構 造に移行するものと推定している。

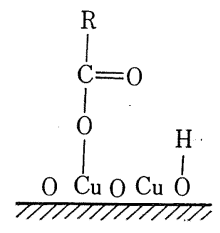

(a)

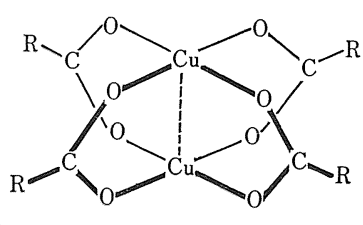

(b)
反射法には全反射法と偏光反射法があるが，金属上の 薄膜の測定法としては後者がすぐれており，今後吸着膜 の有力な研究手段として多用されるものと思われる。詳 細は引用文献にゆずるが，偏光反射法の利点としては，

(1) 入射面に平行な偏光を用いると反射時の増幅作用に より高感度の測定ができ, 単分子膜のスペクトルが比較 的容易に得られる，(2) 吸收の異方性が測定できる， （3）金属上の有機薄膜の反射スペクトルに透過スペクト ルと吸収位置がかわらない，(4) 屈折率, 吸収係数など の光学定数がわかれば反射率を測定することにより膜厚 が求められる，といった点がある。吸着種の同定を行な った例としては前述の Low らの研究で発光法と併用さ れているほか, Poling9) はベンゾトリアゾールの Cu 上への鉱溶溶液からの吸着を調ベ，ベンゾトリアゾール の $-\mathrm{NH}$ 基の水素が置換されて $\mathrm{Cu}$ 塩となりさらに $-\mathrm{N}$ $=\mathrm{N}-$ 結合が $\mathrm{Cu}$ に配位してポリマー構造を形成してい ると推定している。また Francis ら ${ }^{37)}$ は鋼上に抦ける ステアリン酸バリウムの単分子膜およびルイ積膜を測定 し, 単分子膜の場合には入射面に平行な偏光を用いる と,メチレン基の $\mathrm{CH}$ 伸縮振動およびカルボキシレー トイオンの逆対称伸縮振動による吸収が著しく弱くなる ことを見いだした。これは，これらの振動方向が表面に 対して平行であること, すなわち, 吸着分子が表面に垂 直に配列しているためであると解釈されている。このよ らにスペクトルの異方性により吸着膜の配列状態に関す る情報が得られる。赤外線吸収スペクトルで化学吸着種 を同定する場合には上に述べた諸例のように吸着によっ てスペクトルが明りょらにかかることが必要であって， カルボン膜やカルボン酸塩は同定が容易であるが, スル
ホン酸やスルホネートは扔そらく困難であるら。サビ止 メ剤として用いられる界面活性剤の中ではこのほかリン 酸エステル系が有望であると思われる。Müller ら ${ }^{41)}$ は 金属上ではないが, 無機塩水溶液上のアルキルリン酸エ ステルの吸着膜の研究を行なっている。低分子の極性化 合物の気相からの吸着については蒸着金属粒子を用いる 赤外線吸収法 ${ }^{42}$ や薄い蒸着膜を用いる紫外線吸収法 ${ }^{43}$ が 行なわれており，測定法としては参考になる。

\section{3 油溶性界面活性剤の吸着に及ぼす諸因子}

吸着に及ぼす因子としてまず考えられるのは分子構 造であるが，周知のように界面活性剂は極性基と親油基 からなって预り，この両者の構造により吸着性が異な る。

また一方の被吸着金属の種類も大きな因子であるが, さらに金属上に存在する酸化物, 吸着水分も吸着に影響 する。このほか濃度, 温度, 溶媒, 表面あらさなど多く の因子がある。これらの因子は相互にからみあっており これまでに得られた結果を単純に分類することには無理 があるが，あえて以下のようにまとめることにする。

\section{$3 \cdot 1$ 金属の影響}

はじめに金属の種類により吸着にどのような違いがあ るかを調べてみよう。極性基をもつ化合物では先に紹介 したように金属との相互作用の種類が多いのでもっとも 単純な無極性の 炭化水素の吸着から述べる。Zisman ${ }^{44)}$ らは $\mathrm{C}_{6} \sim \mathrm{C}_{16}$ の n-パラフィン, シクロヘキサン, ベン ゼン，トルエンそのほかを各種金属に吸着させ，これら が金属面上に平らに吸着して単分子層を形成すること, 吸着膜の表面電位は金属によって異なることを見いだし ている。図-6 に示すように表面電位と 金属の表面にお ける静電場の強さ，すなわち金属の伝導電子を取りだす のに必要な最高エネルギーとの間に直線関倸があり, 無 極性分子の吸着は金属の静電場によって誘起された分子 分極と静電場の相互作用によるものといえる。一方, 極 性基が吸着する場合の下地金属の影響について同じく Zisman ら ${ }^{24)}$ はステアリン酸の吸着性が 図-7 に示すよ らに金属の共有結合半径, 遷移金属にあっては金属原子

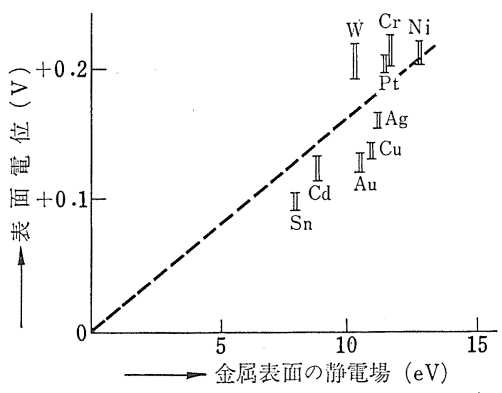

図-6 各種金属上の $n$-ヘキサン吸着膜 の表面電位 ${ }^{44}$ 


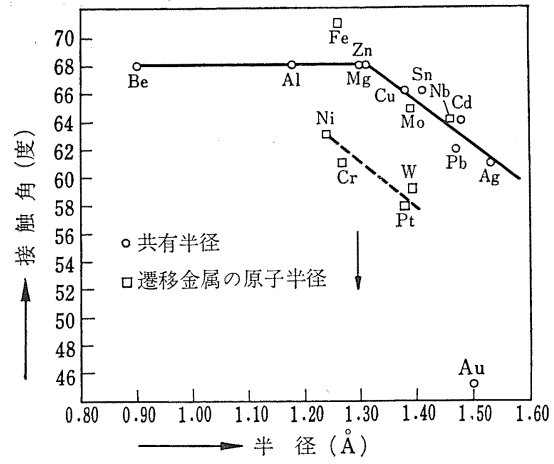

図-7 各種金属上のステアリン酸単分子膜に対する ヨウ化メチレンの接触角と金属の共有結合半 径の関係 ${ }^{24)}$

半径, と直線的な関係があり, いずれも原子半径が小さ くなるほどよりチュウ密配列をすると報告している。と くに遷移金属以外の金属ではステアリン酸が最チュウ密 配列をした時の分子間距離 $1.29 \AA$ がちょうど共有結合 半径の 2 倍に等しい $\mathrm{Zn}, \mathrm{Mg}$ で吸着性が最大となって おり，極性基と金属原子の吸着面における対応が重要で あることを示している。しかしZisman らの用いてい る金属はすべて多結晶であるからこのよらに単純に解釈 できるものか疑問がある。Grindstaff ら ${ }^{13}$ は Cu の単 結晶面へのノナデカン酸およびウンデカン酸の吸着を測 定した結果, 前者では異方性が認められなかったが後者 では（100）面がもっとも吸着性が大きいのに対して， (110)，(111）および (311) 面の吸着性は小さいことを 報告しており，吸着に金属表面の原子密度が影響するこ とは確かであろう。

吸着実験に用いる金属表面は通常の研摩方法では程度 の差があるにしても酸化膜でおおわれていると考えるべ きであり，また実用面への応用を考える場合にはむしろ 酸化物上への吸着を研究するべきであるともいえる。こ のために多くの研究が行なわれている。Timmons ら ${ }^{24)}$ は $\mathrm{Pt}$ および $\mathrm{NiO}$ 上のステアリン酸の単分子吸着膜を エーテルで脱着した結果，前者は $1 \mathrm{hr}$ の抽出で完全に 脱着されるが後者は $4 \mathrm{hr}$ かけても20\% 程度しか脱着さ れないことから，ステアリン酸は $\mathrm{Pt}$ 上で物理吸着をし ており， $\mathrm{NiO}$ 上では化学吸着をしているとしている。 Grün ら $^{45}$ は反射赤外線吸収スペクトルを用い 50 100 $\mathrm{C}$ で直鎖脂肪酸 $\left(\mathrm{C}_{12} \sim \mathrm{C}_{16}\right)$ を金属および金属酸化物に 吸着させたときの吸着種を調べている。 $\mathrm{Cu}, \mathrm{Pb}, \mathrm{Zn}$ は 金属および酸化物とも塩を形成するが， $\mathrm{Al}, \mathrm{Ni}, \mathrm{Cd}, \mathrm{Fe}$

（鋼球材）は金属では反応せず酸化物になるとわずかに 1,500 1,700 $\mathrm{cm}^{-1}$ の吸収が増加する。この結果からみ ると化学吸着といっても塩を形成する場合ともっと弱い 相互作用があることがわかる。この点については前項で 紹介したエステル結合の可能性と合わせて今後明らかに

されるものと思われる。カルボン酸以外の界面活性剤に ついてはあまり研究が行なわれていないが, DNNS 塩 でもカルボン酸と同様な傾向があるよらである。 Smith ら)の結果によれば $\mathrm{Au} へ$ へ $\mathrm{Ca}(\mathrm{DNNS})_{2}$ 吸着は可逆 であり，物理吸着であることを示しているが，一方， Kennedy ら ${ }^{11)}$ は $\mathrm{Na} \cdot \mathrm{DNNS}, \mathrm{Ba}(\mathrm{DNNS})_{2}$ の $\mathrm{Ni}_{2} \mathrm{O}_{3}$ および $\mathrm{Fe}_{2} \mathrm{O}_{3}$ の吸着の場合には吸着速度に比べて脱着 速度がきわめて小さいことからスルホン酸の酸素と下地 金属原子との配位結合，あるいは吸着水の $\mathrm{OH}$ 基と陽 イオンあるいは表面の酸素と陽イオンの相互作用を推定 しており，完全な化学吸着でないにしても物理吸着以上 の相互作用があるとしてよいであろう。これらの結果を 見ると少なくとも Pt P A u のような化学的に安定な金 属の場合はすべて物理吸着であると思われる。酸化物に よって吸着性が大きくなることはこのほか Smith ら ${ }^{46)}$ によってn-ノナデカン酸の $\mathrm{Cu}, \mathrm{Ni}, \mathrm{Fe}$ および $\mathrm{Al}$ へ の吸着で認められている。この研究で酸化物が存在しな い場合の吸着量は $\mathrm{Cu}$ がもっとも多く 1 分子層である がそのほかはいずれも 0.5 分子層前後しか吸着しない。 これに対して酸化物ではいずれも多分子吸着をしてい る。しかしながら Grindstaff ら ${ }^{13)}$ は $\mathrm{Cu}$ 単結晶上に生 成させた $\mathrm{Cu}_{2} \mathrm{O}$ への脂肪酸の吸着ではむしろ $\mathrm{Cu}$ より吸 着性が低下することを報告しており，吸着に影響する因 子をさらに統一的に検討する必要がある。終りに金属表 面の現象が複雑であることを示す例をあげておこう。 $\mathrm{Pt}$ や Au の場合には表面状態を規定することが比較的容 易であると考えられるがそれにもかかわらず，これらの 表面の水によるぬれについて Zisman ${ }^{47), 48)}$ と $\operatorname{Erb}^{49), 50)}$ の間に論争が行なわれている。すなわち Zisman らは 清浄な Pt, Au の表面に水は広がるものであり, 広がら ない場合はすべて有機物による表面污染によるためと主 張しているが，一方 Erb は Zisman らの行なった実験 上の問題点を取り上げ，表面が清浄な場合には水は広が らずに有限の接触角を示すものであり, 広がる場合は逆 に地金中の不純物金属その他による無機的な表面污染に よるものとし，さらに Fowkes の理論51) を援用して反

表-1 スルホネートの軟鋼への 吸着に及ぼす湿度の影 響 ${ }^{31)}$

\begin{tabular}{c|c|c}
\hline \multirow{2}{*}{$\begin{array}{c}\text { 相対湿度 } \\
(\%)\end{array}$} & \multicolumn{2}{|c}{ 計数率 $(\mathrm{cpm})$} \\
\cline { 2 - 3 } & \multicolumn{1}{|c|}{$\mathrm{I}$} & \multicolumn{1}{|c}{ II } \\
\hline 0 & 34 & 54 \\
40 & 60 & 58 \\
50 & 113 & 182 \\
70 & 373 & 454 \\
80 & 564 & 590 \\
90 & 562 & 693 \\
100 & 609 & 740 \\
\hline
\end{tabular}

論している。このよう に金属表面に関する現 象は不明な点が多い。

\section{$3 \cdot 2$ 水の影響}

水は吸着を促進する 場合と抑制する場合が あることが知られてい る。Van Hong $ら^{31)}$ は ${ }^{45} \mathrm{Ca}$ 標識 $\mathrm{Ca} \mathrm{DN}$ NS の低炭素鋼への吸 着に及ぼす湿度の影響 を検討した。表-1 は 
表-2 ステアリン酸の吸着に及 ぼすふんい気の影響133

\begin{tabular}{c|c|c|c|c}
\hline \multirow{2}{*}{ ふえん気 } & \multicolumn{2}{|c}{ 吸着量* (分子層) } \\
\cline { 2 - 4 } & $\mathrm{Fe}$ & $\mathrm{Au}$ & $\mathrm{Cu}$ \\
\hline \multirow{2}{*}{$\mathrm{He}$} & Dry & 0.9 & 0.0 & 0.3 \\
& Wet & 0.5 & 0.3 & 0.4 \\
\hline \multirow{2}{*}{ 空 気 } & Dry & 1.2 & 0.6 & 0.4 \\
& Wet & 0.4 & 0.2 & 9.0 \\
\hline
\end{tabular}

*n一ヘキサデカン 溶液に $35^{\circ} \mathrm{C} \times$ $70 \mathrm{hr}$ 浸七キ後

$\mathrm{Ca}, \mathrm{Ba}, \mathrm{Cs}, \mathrm{Ni}$ 塩のステンレス鋼上への吸着に及ぼ す水分の影響を検討し，水分を飽和した場合にはすべて 遊離の DNNS と同一の吸着を示し, 陽イオンが影響し ないことおよび無水の場合より吸着性が大きいことを明 らかにしている。Hirst ら ${ }^{12)}$ はステアリン酸の吸着に及 ぼす水分の影響を調べたが， $\mathrm{TiO}_{2}, \mathrm{SiO}_{2}, \mathrm{TiC}$ あるいは $\mathrm{SiC}$ のように化学的に安定な物質への吸着は水分の存 在によって抑制されるのに対して $\mathrm{Cu}$ および $\mathrm{Zn}$ の場 合は金属でも酸化物でも水分によって吸着は促進され， とくに酸化物に対して効果が著しいことを認めている。 また同じ $\mathrm{Cu}$ の酸化物でも $\mathrm{Cu}_{2} \mathrm{O}$ と $\mathrm{CuO}$ では水の影 響に大きな差があり，前者のほらがはるかに大きい。同 ビくステアリン酸について Walker ら ${ }^{3)}$ は $\mathrm{Au}, \mathrm{Fe}$ お よび $\mathrm{Cu}$ の蒸着膜を用い, 酸素および水分の影響を調 べている。その結果の一部はすでに紹介したが，表-2 に $35^{\circ} \mathrm{C} \times 70 \mathrm{hr}$ 後の吸着量の 測定結果を示す。この結 果を見ると Fe の場合には酸化物の有無にかかわらず 無水状態のほらが吸着しやすいのに対して $\mathrm{Cu}$ ではとく に酸化物と水分が共存するときにきわめて大きい吸着が 起きることがわかる。一方，Au の場合ははっきりした 法則性が見られない。以上の結果からわかるように, 水

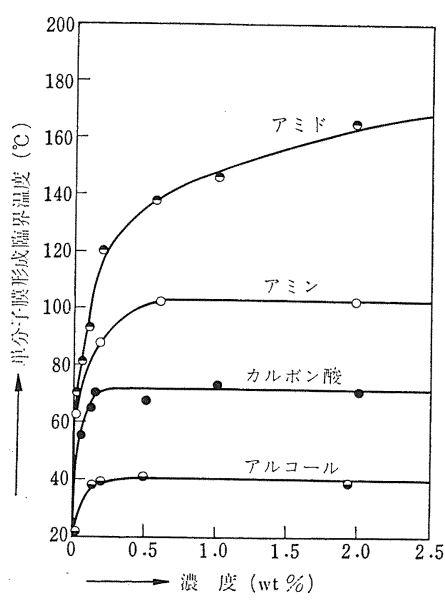

図-8 炭素数18の化合物の単分子膜 の形成に及ぼす濃度および極 性基の影響 $(n \text {-ヘキサデカン濃度 })^{42}$

約 $18^{\circ} \mathrm{C}$ で $25 \mathrm{hr}$ 放置 したときの吸着量を示 す。これからわかるよ らに, $\mathrm{Ca}(\mathrm{DNNS})_{2}$ の 吸着は水分の存在によ り著しく促進され，相 対湿度が 40〜80\%の 間では比例関係があ る。 Singleterry $ら^{27)}$ は DNNS とその $\mathrm{Na}$,
分の吸着に及ぼす影響は吸着物質と金属表面の性質によ って異なり現在のところではさらにデータの集積が必要 である。

\section{3 -3 界面活性剂の分子構造の影響}

吸着に及ぼす分子構造の影響は直鎖脂肪族のカルボン 酸，アミン，アミドおよびアルコールについてよく研究 されている。Bigelow ら ${ }^{52)}$ はこれらの $n$-セタン溶液か ら Pt 上に蹯油性単分子膜が形成する条件を検討し, 図 -8 に示すよらな結果を得た。Gibbs の等温吸着式から 予想されるように疎油性単分子膜は溶液の濃度が高いほ どできやすく，反対に温度が高いほどできにくい。この ため，図に示すよらに濃度が一定ならばある臨界温度以 上では蹯油性単分子膜，いいかえればチュウ密配列の単 分子膜ができなくなる。またこの臨界温度はある濃度以 上で一定になる。Bigelow らはこのような現象が吸着 分子の熱運動によって脱着速度が大きくなり，きれいな 分子配列をとりえなくなためであると考え, 統計力学 的な考察によって式 (2) を導き, 臨界温度の濃度変化 から全吸着エネルギーを計算した。

$$
\begin{aligned}
C= & A_{\text {exp }} \cdot(-U / R T) \\
& C: \text { 濃度, } A: \text { 定数, } U: \text { 全吸着エネルギー, } \\
& T: \text { 臨界温度 }
\end{aligned}
$$

ここで全吸着エネルギーを極性基による吸着エネルギ - $\left(U_{o}\right)$ と親油基閒の横方向の吸着エネルギー $\left(U_{c}\right)$ の 和とし, 炭素数の大きい直鎖炭化水素基では $U_{c}$ がメチ レン基の数に比例するとすると, 全吸着エネルギーは次 式で表わされる。

$$
\begin{aligned}
& U=U_{o}+U_{c}=U_{o}+N \cdot u \\
& u: \text { メチン基 } 1 \text { 個当たりの吸着エネルギー, } \\
& N: \text { 炭化水素基の炭素数 }
\end{aligned}
$$

さらに同族体たとえば直鎖脂肪酸の炭素数 $(N)$ とそ れらの溶融状態（濃度 $100 \%$ と考えられる）加らの疎 油性単分子膜形成の 臨界温度 $(t)$ の関係から次式を導 き,メチレン基 1 個当たりの吸着エネルギー（u）を計 算した。

$$
u=b^{2} R \quad \partial t / \partial N
$$

\begin{tabular}{|c|c|c|c|c|c|c|}
\hline 化 合 物 & $\begin{array}{r}\text { 全吸着エネ } \\
\text { ルギー(U) } \\
\mathrm{cal} / \mathrm{mol}\end{array}$ & $\begin{array}{l}\text { 臨界温度 } \\
(\tau),{ }^{\circ} \mathrm{K}\end{array}$ & $\begin{array}{l}\mathrm{b}^{2} \\
\text { 式(4)よ } \\
\text { り }\end{array}$ & $\begin{array}{c}\text { メンレン基 } 1 \\
\text { 個当たり凝 } \\
\text { 集エネルギー } \\
\begin{array}{c}(u), \\
\mathrm{cal} / \mathrm{mol}\end{array}\end{array}$ & $\begin{array}{l}\text { 極性基によ } \\
\text { る吸着エネ } \\
\text { ルキキ } \\
(U o) \\
\quad \mathrm{cal} / \mathrm{mol}\end{array}$ & 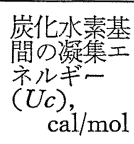 \\
\hline $\mathrm{C}_{18}$ アルコール & 10,000 & 393 & 12.8 & 188 & 6,600 & 3,400 \\
\hline $\mathrm{C}_{18}$ 脂 肪 酸 & 10,000 & 378 & 13.3 & 212 & 6,200 & 3,800 \\
\hline $\mathrm{C}_{18} \supset ミ ン$ & 14,500 & 508 & 14.4 & 336 & 8,400 & 6,100 \\
\hline $\mathrm{C}_{18} \curlyvee ミ$ & 13,700 & 468 & 14.7 & 103 & 11,900 & 1,800 \\
\hline
\end{tabular}

上式で $b^{2}$ は吸着分子の熱運動による脱着の確率に関 係する定数であり， $R$ は気体定数である。

表-3 の計算結果に見られるよ5に，炭素数 18 の酸, アミド，アミンおよびアルコールでは炭化水素基間の吸

表-3 直鎖脂肪族化合物への白金上への吸着エネルギー ${ }^{52)}$ 
着エネルギー（凝集エネルギー）は平均して全吸着エネ ルギーの $40 \%$ 近くに達しており，このような $\mathrm{Pt}$ 上の 物理吸着の場合にはかなり大きな寄与をしていることが わかる。一方，極性基の吸着エネルギーを比較するとア ミド>アミン>アルコールニ酸の順序になる。このほか 極性基の吸着性の比較は以下のようにして行なわれてい る。Fowkes ${ }^{10)}$ は吸着性の強さは吸着速度, 吸着平衡お よび吸着膜のち密さのいずれでも表わすことができると し，これらを総合してつぎのようにホワイトオイル溶液 からの酸, アミンおよびアルコールの吸着性を評価し た。ここでアミンの吸着性は三つの金属で変わらない が，酸はステンレス鋼には吸着性が低く，Al に対して は強い。これは金属表面の酸性度の違いによるものであ る。

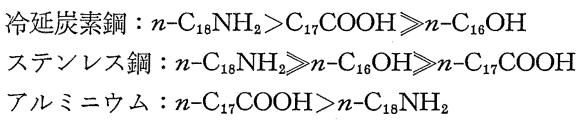

上の結果をみると酸よりアミンのほうが吸着性が大き いからサビ止メ効果もアミンのほうが良さそうに思われ るが，実際には逆になる ${ }^{53)}$ 。Block らら ${ }^{29)}$ はオタデシルア ミンおよびステアリン酸のビシクロヘキシル溶液から, 低炭素鋼上への吸着, 脱着および交換を測定した結果， 溶剤による脱着が両者とも同程度で差がないにもかかわ らす，吸着膜中の分子と溶液中の分子の間でおきる交換 ではアミンがかなり速やかに交換するのに対して酸では ほとんど交換が起こらないことを見いだした。この結果 から酸とアミンのそれぞれ $40 \%$ 程度は強固に吸着して いるが, 酸の場合にはおそらく化学吸着によって吸着し ているために交換が起こらず，アミンの場合には水素結 合によって吸着しているために交換が起こり，したがっ て, 酸の吸着膜のほうがより強固であり, そのために酸 のサビ止メ性がすぐれていると結論される。アミンが交 換しやすい理由として Block らはアミンはその窒素と 金属面に吸着している水の水素との間の水素結合で吸着 しているが，ここに溶液から別のアミンが近うくと，吸 着水の酸素とそのアミンの水素との閒に水素 結 合を生 し，このために吸着していたアミンの水素結合が切れて 交換が起きるといら機構を考えている。

スルホネート $\left(\mathrm{Ca}(\mathrm{DNNS})_{2}\right)$ とポリアルコールおよ びポリエステルの $\mathrm{Au}$ 上における物理吸着の吸着性に ついて Smith ら ${ }^{4)}$ は Langmuir の等温吸着式を多成分 系溶液に適用し, 相対吸着性を求めている。この結果に よると極性基 1 個当たりの吸着性はスルホネート>アル コール>エステルとなる。スルホネートの陰イオンの吸 着性に及ぼす影響は二,三の研究がある。Kennedy ら ${ }^{11)}$ は $\mathrm{Ni}_{2} \mathrm{O}_{3}$ と $\mathrm{Fi}_{2} \mathrm{O}_{3}$ へのシクロヘキサン溶液からの $\mathrm{Na}$ ・ DNNS および $\mathrm{Ba}(\mathrm{DNNS})_{2}$ の吸着性を吸着平衡によっ て比較しているが，Ba 塩のほうがやや吸着性が大きい。
この理由は明らかでないが， $\mathrm{Na}$ イオンより $\mathrm{Ba}$ イオン のほらがイオン半径が大きいので表面に吸着している水 酸基と相互作用が大きいためかあるいは溶液中の溶存状 態に関係するものと推定している。しかし, 吸着平衡デ 一タのラングミュア・プロットによって得られるパラメ 一ターから計算した飽和吸着時の分子の占有面積は, $\mathrm{Na}$ 塩の場合には, $\mathrm{Ni}_{2} \mathrm{O}_{3}$ 上で $68 \AA^{2}, \mathrm{Fe}_{2} \mathrm{O}_{3}$ 上で 109 $\AA^{2}$ となる。この $\mathrm{Ni}_{2} \mathrm{O}_{3}$ 上の值は $\mathrm{Na}$. DNNS 最チュウ 密配列していることを示す。また $\mathrm{Ni}_{2} \mathrm{O}_{3}$ のほうが $\mathrm{Fe}_{2} \mathrm{O}_{3}$ より吸着量が大きい。これは $\mathrm{Ni}_{2} \mathrm{O}_{3}$ の $\mathrm{Ni}$ の原子間距 離が $2.49 \AA$ および $3.52 \AA$ でちょうど, Na・DNNS の極性基の間隔に等しく前述の脂肪酸の金属上への吸着 の場合と同椂な理由で説明できるかも知れない。このほ か, 飽和吸着における吸着量は DNNS 塩の陰イオンで 比較すると $\mathrm{Na}$ 塩でも $\mathrm{Ba}$ 塩でも変わらない。これに 対して Singleterry ら ${ }^{27)}$ は各種 DNNS 塩のイソプロピ ルビフェニル溶液からのステンレス鋼上への吸着を測定 しているが, 吸着膜のチュウ密性から考えると水分が存

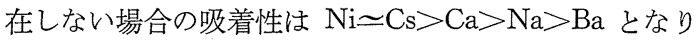
Kennedy らの結果と異なっている。これは下地金属と 溶媒が同じでないためであろら。水分が存在する場合に 陰イオンによる差がないことはすでに述べた。

つぎに吸着に及ぼす親油基の影響であるが，前述の Bigelow らの研究以外にも興味のある現象が知られてい る。Timmons $~^{24)}$ は $\mathrm{C}_{1} \sim \mathrm{C}_{26}$ までの直鎖脂肪酸の $\mathrm{Pt}$ および $\mathrm{NiO}$ 上の吸着膜の表面電位を測定し，図-9 に 示す結果を得た。Pt および $\mathrm{NiO}$ 上のいずれの場合も 炭素数 $\geqq 14$ で表面電位は一定值に達する。このことは 炭素数 14 以上でチュウ密配列の単分子層を形成するこ とを示し，炭化水素基間の相互作用が吸着に影響してい ることを示す。Martin ら ${ }^{25}$ は $\mathrm{Cr}$ 上で同様な測定を行 なっているが，この場合には炭素数 $\geqq 18$ で表面電位が 一定值になっている。図-9 に見られるように $\mathrm{NiO}$ 上 の表面電位は炭素数が奇数と偶数でそれぞれ別の線上に 乗っており奇数のもののほうが高い。Timmons らはさ らにステアリン酸とノナデカン酸の 17 種の金属上にお ける単分子膜の表面電位を比較し, $\mathrm{Pt}$ や $\mathrm{Au}$ のような

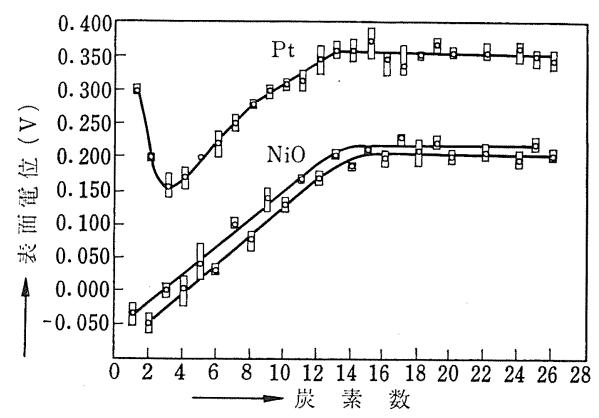

図-9 直鎖脂肪酸吸着膜の表面電位の炭素数 による変化 
反応性のない表面では両者とも同じ表面電位を示すのに 対して他の大部分の金属上ではノナデカン酸のほうが大 きい表面電位を示すことから，奇数の炭素数の直鎖脂肪 酸は物理吸着以上の相互作用をもつものと推定してい る。このほが直鎖脂肪酸の炭素数は吸着の初期にできる 島状の吸着膜の大きさや単分子膜に見られる穴にも影響 し, 炭素数が小さくなるほど島は小さくなり穴もできや

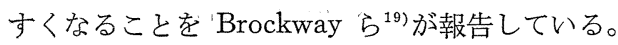

\section{4 吸着に及ぼすその他の因子}

これまでに述べてきたように物理吸着の場合には温度 を上げると吸着しにくくなるが， $\mathrm{Cu}$ 上の脂肪酸のよう な化学吸着は温度を上げることによって促進される。ま たもし水素結合で吸着しているとすれば昇温により脱着 が起こるであろう。Kennedy ら ${ }^{11}$ は $\mathrm{Ni}_{2} \mathrm{O}_{3} へ$ へa・ DNNS の吸着の場合には室温から $60^{\circ} \mathrm{C}$ まで上げても 脱着は $1 \%$ 程度しか起こらず，したがって化学吸着を しているものとしている。Brockway $ら^{23)}$ は表面のあら さがあらいほど直鎖脂肪族の酸，アミンなどのチュウ密 配列の吸着速度が小さいことを電子回折による実験で報 告している。Timmons $~^{\left.{ }^{28}\right)}$ は $\mathrm{Fe}$ 上へのステアリン酸 の吸着で, $600 \operatorname{grit}(14 \mu)$ 研摩と $400 \operatorname{grit}(24 \mu)$ 研摩で 後者の場合には retract 法によって単分子膜ができない ことを認めている。この結果から少なくとも直鎖脂肪族 の炭化水素基をもつ界面活性剂の吸着には表面のあらさ が影響すると考えられる。これは拉そらく炭化水素基間 の横方向の吸着が，表面のおうとつで妨げられるためで あ万弓。Fowkes ${ }^{54}$ は液一液界面における吸着速度が 80 〜 90\% の単分子膜が生成するまでは拡散理論からの計 算値と一致することを確かめているが，固-液界面の吸 着では理論值より $10^{-5}$ も遅〈なる ${ }^{10)}$ 。これは固体状に 吸着した分子が動き得ないために，吸着しよらとして表 面に到達した分子がこれを押しのけて吸着することがで きず，そのために吸着が自由に起こらないためであると 説明されている。この結果からすると，吸着速度に及ぼ すかきまぜの効果は少なくなりそうであるが， Smith ${ }^{4}$ らは $\mathrm{Ca} \cdot \mathrm{DNNS}$ の $\mathrm{Au}$ 上への吸着速度がかきまぜによ り約 45 倍も加速されると報告している。

\section{4 多分子吸着}

これまで扱ってきた吸着現象は主として単分子吸着だ ったが，二，三の例に見られたよらに多分子吸着をする 場合も西った。多分子吸着はサビ止入剂の実用性能から するといわゆるオイルステインに関係があると思われる のであらためてまとめてみることにしたい。

Bowden $ら^{55)}$ は物理吸着と化学吸着を区別する方法 として,放射化した金属ハクをステアリン酸,ステアリン 酸エチルおよびオクタデシルアルコールのベンゼン溶液 中に浸セキし，溶液中に溶解する金属量およびさらに試
表-4 ステアリン酸の吸着に及ぼす水分の影響 ${ }^{122}$

\begin{tabular}{|c|c|c|c|c|}
\hline \multirow{2}{*}{$\begin{array}{l}\text { 被 吸 差 } \\
\text { 物 粉末) } \\
\text { 頪末 }\end{array}$} & \multirow{2}{*}{$\begin{array}{c}\text { 表 面 積 } \\
\left(\mathrm{m}^{2} / \mathrm{g}\right)\end{array}$} & \multirow{2}{*}{$\begin{array}{l}\text { ステアリン酸の } \\
\text { 単分子層吸着時 } \\
\text { の吸着 } \\
\begin{array}{c}\text { (mg) } \\
\text { (mg }\end{array}\end{array}$} & \multicolumn{2}{|c|}{ 吸着量 $\left(18^{\circ} \mathrm{C} \times 5 \mathrm{hr}\right)$} \\
\hline & & & $\begin{array}{l}\text { Dry } \\
\text { (mg) }\end{array}$ & $\begin{array}{l}\text { Wet } \\
\text { (mg) }\end{array}$ \\
\hline $\mathrm{Zn}^{*}$ & 0.3 & 0.7 & 0.5 & 4.3 \\
\hline $\mathrm{ZnO}$ & 3.7 & 8.6 & 25.6 & 46.8 \\
\hline $\mathrm{Cu}^{*}$ & 8.2 & 18.6 & 4.4 & 14.0 \\
\hline $\mathrm{Cu}_{2} \mathrm{O}$ & 5.4 & 12.3 & 0.2 & 128 \\
\hline $\mathrm{CuO}$ & 22.7 & 51.6 & 53 & 98 \\
\hline
\end{tabular}

* とくに表面酸化膜は除いていない。

料のベンゼン抽出によって得た吸着膜中の金属量を放射 能測定によって定量することを行なっているが，反応性 の大きい $\mathrm{Cd}, \mathrm{Zn}, \mathrm{Cu}$ のちちたとえば $\mathrm{Cu}$ では $40 \mathrm{~min}$ の浸セキで溶液中に 100 分子層, 吸着膜は 5 分子層が

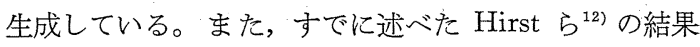
を表-4 に示すが，これをみても水分が存在する条件で $\mathrm{Cu}_{2} \mathrm{O}$ 拉よび $\mathrm{ZuO}$ はステアリン酸と強く化学吸着し, とくに $\mathrm{Cu}_{2} \mathrm{O}$ では 10 分子層にも達している。さらに図 -2 に見られるように, やはり $\mathrm{Cu}$ は酸素と水の共存で ステアリン酸により多分子吸着することが明らかであ る。この多分子層は溶剤で洗らことにより単分子層まで に落ちる。このような事実加ら多分子層は金属表面に化 学吸着した単分子層の上に吸着が進行することによって 生ずる金属塩がさらに物理吸着しているものといえよ う。多分子吸着するものは文献上で著者の知る限りでは 油溶性界面活性剂のらち脂肪酸のみであるが, 当然, 条 件にようてはスルホネートやカルボキシレートでも生成 すると考えられる。

\section{5 混合 吸着膜}

最後にサビ止メ剂のサビ止メ性に密接な関係がある溶 媒その他のいわ河る油分と界面活性剤の混合吸着膜につ いて述べよう。サビ止入剂に油分が必要であることは，

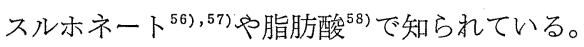

Bewig および Z isman ${ }^{7}$ は直鎖脂肪酸アミンの直鎖脂 肪族炭化水素溶液から Pt 上に retract 法で単分子膜を 作り表面電位により吸着膜中の溶質と溶媒の割合を算出

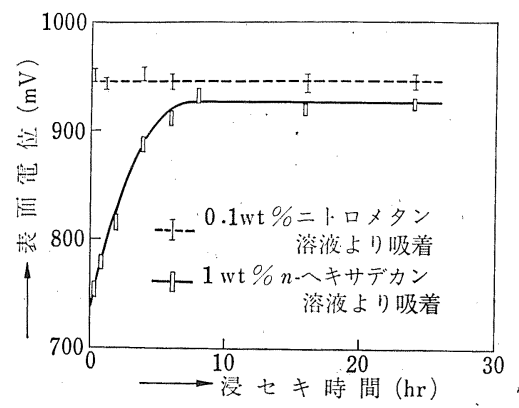

図-10 白金上のオクタデシル単分子膜の表面電位 ${ }^{7}$ 
し，同時にヨウ化メチレンの接触角の測定によって吸着 膜の炭化水素基の配列状態を調べている。図-10 亿示 すようにオクタデシルアミンのへキサデカン溶液からの 吸着速度とニトロメタン溶液からの吸着速度には大きな 差がありしかも吸着平衡における表面電位はへキサデカ ン溶液のほらが低い。これはへキサデカン溶液からの吸 着では混合吸着が起こるのに対して, ニトロメタンは直 鎖状分子と著しく形状が異なるのでその溶液の場合には 混合吸着が起こらないためである。アミンと溶媒の炭素 数の組合せをかえて 図-10 のような測定を行ならと， 直鎖脂肪族アミンと同じ炭素数をむつ直鎖炭化水素の溶 液の場合にもっとも溶媒の吸着量が大きくなる。吸着平 衡における吸着膜中の溶媒の mol\% は平均して $15 \%$ である。したがって下図のようにアミンの 7 分子が 1 個 の溶媒分子を取り囲むような構造が考光られる。この場 合, 溶媒分子の mol\% は $14.3 \%$ となる。以上の結果 から側鎖を有する溶媒では混合膜を作りにくいと考えら れるが実際に長鎖脂肪族アミンと 1ーフェニルドデカン， プリスタン，スクワランなどはほと

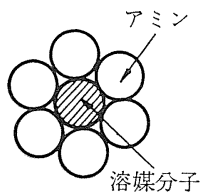
んど混合膜を形成しない。 Doyle ら ${ }^{59)}$ は $\mathrm{Fe}, \mathrm{Cu}, \mathrm{Ag}$ および $\mathrm{Au}$ 上へ のステアリン酸と $n$-オクタデカン の混合吸着を RI法で調べているが， 単分子膜より厚い混合膜ができるこ とから，この場合には，溶媒はステアリン酸の吸着膜中 にある穴（カルボキシル基と炭化水素基の断面積の差が あるために生ずる）にはいり，これらの分子をアンカー として溶媒が吸着するものと推定している。

\section{6 おわりに}

これまでに行なわれた多くの吸着現象に関する研究は 直接に辛ビ止メ剂の作用機構を解明することを目的とし ているものが比較的少ない。このためにわれわれサビ止 メ油の開発研究に従事するものにとって知りたいことと 得られた結果の間にはかなりの空白が残されているよう に思われる。本報ではこの空白を少しでも埋めることを 意図したものであるが著者の浅学のゆえに充分その目的 を達することができなかった。本報が多少とも御参考に なればまことに望外の幸せである。

\section{（昭和 46 年 5 月 10 日受理）}

\section{文献}

1) 渡辺, 油化学, 18, 588 (1969)

2) H.E. Ries, Jr., H.D. Cook, J. Colloid Sci., 9, 535 (1954)

3) D.C. Walker, H.E. Ries, Jr., Adv. Chem. Ser., 43, 295 (1964)

4) M.L. Smith, B.E. Gordon, R.C. Nelson, J. Phys . Chem., 69, 3833 (1965)

5) W.A. Zisman, Adv. Chem. Ser., 43, 1 (1963)

6) W.C. Bigelow, D.L. Pickett, W.A. Zisman, J. Col- loid Sci., 2, 513 (1947)

7) K.W. Bewig, W.A. Zisman, J. Phys. Chem., 67, 130 (1962)

8) J. Maddox, Jr., R.H. Graves, Preprint ACS Mtg. Petrol. Chem. Div. D-69 (1965)

9) G.W. Poling, Corrosion Sci., 10, 359 (1970)

10) F.M. Fowkes, J. Phys. Chem., 64, 726 (1960)

11) P. Kennedy, M. Petronio, H. Gisser, 74, 102 (1970)

12) W. Hirst, J.K. Lancaster, Trans. Farad. Soc., 47, 315 (1951)

13) T.H. Grindstaff, H.A. Smith, W.W. Harris, J. Colloid Sci., 20, 341 (1965)

14) 山科, 化学々工業, 22, 889 (1969)

15) G.L. Gaines, Jr., J. Colloid Sci., 15, 329 (1960)

16) A.H. Ellison, J. Phys. Chem., 66, 1867 (1962)

17) T. Smith, J. Colloid Interface Sci., 30, 183 (1969)

18) O. Levine, W.A. Zisman, J. Phys. Chem., 61, 1068 (1957)

19) L.O. Brockway, R.L. Jones, Adv. Chem. Ser., 43, 275 (1964)

20) M.J. Vold, J. Colloid Sci., 7, 196 (1952)

21) J.J. Kipling, A.D. Norris, 8, 547 (1953)

22） L.O. Brockway, R.L. Livington, 未発表データ

23) L.O. Brockway, J. Karl, J. Colloid Sci., 2, 277 (1947)

24) C.O. Timmons, W.A. Zisman, J. Phys. Chem., 69, 984 (1965)

25) B.J. Bornong, P. Martin, Jr., J. Phys. Chem., 71, 3731 (1967)

26) P. Martin, B.J. Bornong, J. Phys. Chem., 72, 4172 (1968)

27) W.D. Bascom, C.R. Singleterry, J. Phys. Chem., 65, 1683 (1961)

28) C.O. Timmons, R.L. Patterson, L.B. Lockhart, Jr., J. Colloid Interface Sci.,26, 120 (1968)

29) A. Block, B.B. Simms, J. Colloid Interface Sci., 25, 514 (1967)

30) H. Schonhorn, J. Colloid Sci., 18, 445 (1963)

31) Van Hong, S.L. Eisler, D.Bootzin, A. Harrison, Corrosion, 10, 343 (1954)

32) A.J. Groszek ASLE Trans., 13. 278 (1970)

33) M.J.D. Low, M. Hasegawa, J. Colloid Interface Sci., 26, 95 (1968)

34) M. Hasegawa, M.J.D. Low, J. Colloid Interface Sci., 29, 593 (1969)

35) M. J. D. Low, H. Inoue, Can. J. Chem, 43, 2047 (1965)

36) M. J. D. Low, K.H. Brown, H. Inoue, J. Colloid Interface Sci., 24, 252 (1967)

37) S.A. Francis, A. H. Ellison, J. Opt. Soc. Am., 49, 131 (1959)

38）末高, 分光研究, 18, 187 (1969)

39) G.W. Poling, J. Colloid Interface Sci., 34, 365 (1970)

40) M. Hasegawa, M.J.D. Low, J. Colloid Interface Sci., 30, 378 (1969)

41) H. Müller, S. Friberg, M. Helisten, J. Colloid Interface Sci., 32, 132 (1970)

42) G. Blyholder, M.C. Allen, J. Colloid Interface Sci., 33, 603 (1970)

43) K. Kishi, S. Ikeda, J. Phys. Chem., 73, 15 (1969)

44) K.W. Bewig, W.A. Zisman, J. Phys. Chem., 68, 
1804 (1964)

45) H. Grün, H.H. Dunken, Erdöl u. Kohle. Erdgas. Petrochemie., 20, 634 (1967)

46) H.A. Smith, K.A. Allen. J. Phys.Chem., 58, 449 (1954)

47) H.W. Fox, E,F. Hare, W.A. Zisman, J. Phys. Chem., 59, 1097 (1955)

48) K.W. Bewig, W.A. Zisman, J. Phys. Chem., 69, 4238 (1965)

49) R.A. Erb, J. Phys. Chem., 69, 1306 (1965)

50) R.A.Erb, J. Phys. Chem., 72, 2412 (1968)

51) F.M. Fowkes, Ind. Eng. Chem., 56 (12), 40 (1964)

52) W.C. Bigelow, E. Glass, W.A. Zisman, J. Colloid Sci., 2, 563 (1947)
53) H.R. Baker, W.A. Zisman, Ind. Eng. Chem., 40, 2388 (1948)

54) F.M. Fowkes, J. Phy. Chem., 57, 98 (1953)

55) F.P. Bowden, C. Moore, Trans. Farad. Soc., 47, 900 (1951)

56) E.R. Barnum, R.G. Larsen, A. Wachter, Corrosion., 4, 423 (1948)

57) A.H. Roebuck, P.L. Gant, O.L. Riggs, J.D. Sudbury, Corrosion., 13, 55 (1957)

58) H.E. Ries, Jr., I. Galor, Chem. Ind., 1561 (1967)

59) W.P. Doyle, A.H. Ellison, Adv. Chem. Ser.. 268 (1964)

60) N. Pilpel, Adv. Colloid Interface Sci., 2, 261 (1969)

\section{特集「脂質の生化学」発行のお知らせ}

（油化学 Vol. 20 No. 10 予定）

最近における脂質生化学の進歩はきわめて顕著である現況に鑑み，脂質の忘用開発の手掛りになるよ う，生体における脂質の機能意義に関連する項目および生物体を中心とした項目を加えて，現下の生化 学界におけるべストメンバーによる研究の現状をわかりやすく紹介するもので会員各位のご期待に添う ものと信じます。

\begin{tabular}{|c|c|c|c|c|}
\hline & & 者 & & 題 \\
\hline 原 & & 一 & 郎 & 脂質の生化学 特集について \\
\hline $\begin{array}{l}\text { 堀 } \\
\text { 板 }\end{array}$ & 坂 & 太 & $\begin{array}{l}\text { 郎 } \\
\text { 修 }\end{array}$ & 脂質の分離抒よび同定法 \\
\hline 藤 & 野 & 安 & 彦 & 脂 質 の生 合成 \\
\hline 赤 & 沼 & 安 & 夫 & 脂肪の吸収と担送 \\
\hline 中 & 村 & 真 & 巳 & 脂質とホルモン \\
\hline 平 & 山 & & 修 & 脂 質 と膜 構 造 \\
\hline 原 & & 一 & 郎 & 脂 質 と 免 疫 \\
\hline 植 & 田 & 伸 & 夫 & 分枝脂肪酸の生化学 \\
\hline 木 & 村 & 修 & 一 & 脂肪酸の不飽和化と鎖長延長 \\
\hline 松 & $\begin{array}{l}\text { 本 } \\
\text { 輪 }\end{array}$ & 匡 & $\begin{array}{l}\text { 亮 } \\
\text { 男 }\end{array}$ & 細 菌の 脂 質 \\
\hline $\begin{array}{l}\text { 金 } \\
\text { 伊 }\end{array}$ & $\begin{array}{l}\text { 子 } \\
\text { 藤 }\end{array}$ & 俊 & $\begin{array}{l}\text { 弘 } \\
\text { 洋 }\end{array}$ & 酵 母 の脂 質 \\
\hline 片 & 山 & 真 & 之 & 植物 の脂質 \\
\hline 野 & 田 & 万次 & 郎 & 種 子の脂 質 \\
\hline 山 & 田 & & 実 & 魚類, プランクトンの脂質 \\
\hline 林 & & & 陽 & 貝 類 の 脂 質 \\
\hline 武 & 富 & & 保 & 血 液 の 脂 質 \\
\hline 林 & & 浩 & 平 & 脳神 経の脂質 \\
\hline 坂 & 上 & 利 & 夫 & 肝 臓 の 脂 質 \\
\hline
\end{tabular}

製品と技術

